ENVIRONMENTAL RESTORATION PROGRAM

\section{Surface Radiological Investigations at the 0816 Site, Waste Area Grouping 13, Oak Ridge National Laboratory, Oak Ridge, Tennessee}

P. F. Tiner

M. S. Uziel 
This report has been reproduced directly from the best available copy.

Available to DOE and DOE contractors from the Office of Scientific and Technical Information, P.O. Box 62, Oak Ridge, TN 37831; prices available from 615-576-8401, FTS 626-8401.

Available to the public from the National Technical Information Service, U.S. Department of Commerce, 5285 Port Royal Rd., Springfield, VA 22161. 
Energy Systems Environmental Restoration Program ORNL Environmental Restoration Program

Surface Radiological Investigations at the 0816 Site, Waste Area Grouping 13, Oak Ridge National Laboratory, Oak Ridge, Tennessee

\author{
P. F. Tiner \\ M. S. Uziel
}

Date Issued-December 1994

Prepared by

Health Sciences Research Division

Oak Ridge National Laboratory

Prepared for

U.S. Department of Energy

Office of Environmental Restoration and Waste Management under budget and reporting code EW 20

OAK RIDGE NATIONAL LABORATORY

Oak Ridge, Tennessee 37831-6285 managed by

MARTIN MARIETTA ENERGY SYSTEMS, INC. for the

U.S. DEPARTMENT OF ENERGY under contract DE-AC05-84OR21400

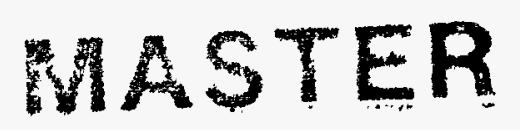




\section{Author Affiliations}

P. F. Tiner and M. S. Uziel are members of the Measurement Applications and Development Group of the Health Sciences Research Division, Oak Ridge National Laboratory, Martin Marietta Energy Systems, Inc., Oak Ridge, Tennessee. 


\section{DISCLAIMER}

Portions of this document may be illegible in electronic image products. Images are produced from the best available original document. 


\section{CONTENTS}

FIGURES

TABLES $\ldots \ldots \ldots \ldots \ldots \ldots \ldots \ldots \ldots \ldots \ldots \ldots \ldots \ldots \ldots \ldots \ldots \ldots \ldots \ldots$

EXECUTTVE SUMMMARY $\ldots \ldots \ldots \ldots \ldots \ldots \ldots \ldots \ldots \ldots \ldots \ldots \ldots$ ix

1. INTRODUCTION $\ldots \ldots \ldots \ldots \ldots \ldots \ldots \ldots \ldots \ldots \ldots \ldots \ldots \ldots$

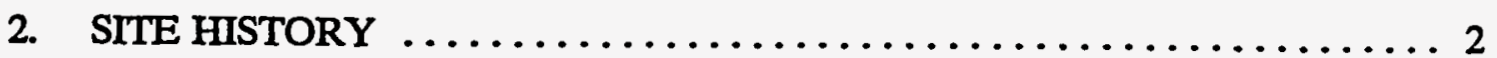

3. SURVEY METHODS $\ldots \ldots \ldots \ldots \ldots \ldots \ldots \ldots \ldots \ldots \ldots \ldots \ldots$

3.1 GAMMA RADIATION $\ldots \ldots \ldots \ldots \ldots \ldots \ldots \ldots \ldots \ldots \ldots \ldots$

3.2 SECTIONING OF SURVEY AREA $\ldots \ldots \ldots \ldots \ldots \ldots \ldots \ldots \ldots \ldots$

3.3 SCOPE OF THE SURVEY $\ldots \ldots \ldots \ldots \ldots \ldots \ldots \ldots \ldots \ldots \ldots$

4. SURVEY RESULTS $\ldots \ldots \ldots \ldots \ldots \ldots \ldots \ldots \ldots \ldots \ldots \ldots \ldots \ldots$

4.1 GAMMA EXPOSURE RATES $\ldots \ldots \ldots \ldots \ldots \ldots \ldots \ldots \ldots \ldots \ldots$

4.2 SOIL SAMPLE ANALYSES $\ldots \ldots \ldots \ldots \ldots \ldots \ldots \ldots \ldots \ldots \ldots \ldots$

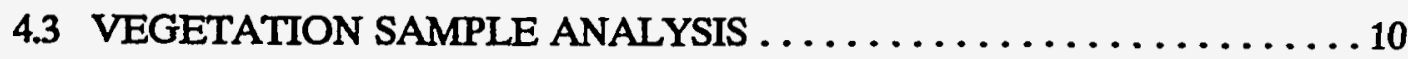

5. SIGNIFICANCE OF FINDINGS $\ldots \ldots \ldots \ldots \ldots \ldots \ldots \ldots \ldots \ldots \ldots$

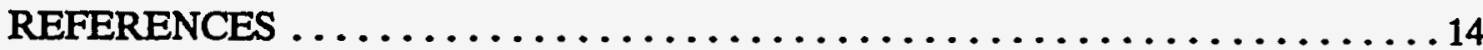

\section{DISCLAIMER}

This report was prepared as an account of work sponsored by an agency of the United States Government. Neither the United States Government nor any agency thereof, nor any of their employees, makes any warranty, express or implied, or assumes any legal liability or responsibility for the accuracy, completeness, or usefulness of any information, apparatus, product, or process disclosed, or represents that its use would not infringe privately owned rights. Reference herein to any specific commercial product, process, or service by trade name, trademark, manufacturer, or otherwise does not necessarily constitute or imply its endorsement, recommendation, or favoring by the United States Government or any agency thereof. The views and opinions of authors expressed herein do not necessarily state or reflect those of the United States Government or any agency thereof. 


\section{FIGURES}

2.1 Diagram of the 5-acre, fenced 0816 site used in ${ }^{137} \mathrm{Cs}$ fallout studies in the $1960 \mathrm{~s}$

3.1 Diagram showing Grid Blocks 1 through 12 established at the

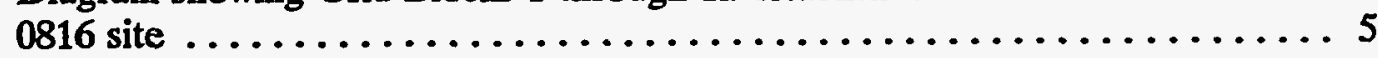

4.1 Diagram showing surface and selected 1-m gamma exposure rates $(\mu R / h)$ in Grid Blocks 1 through 6 at the 0816 site ................. 8

4.2 Diagram showing surface gamma exposure rates $(\mu \mathrm{R} / \mathrm{h})$ and soil sample locations (B) in Grid Blocks 7 through 12 at the 0816 site ........... 9 


\section{TABLES}

4.1 Concentrations of ${ }^{137} \mathrm{Cs}$ in soil (B) and vegetation (V) samples collected at the 0816 site 



\section{EXECUTIVE SUMMARY}

A surface radiological investigation was conducted intermittently from July through September 1994 at the 0816 site, located within Waste Area Grouping (WAG) 13. The purpose of the survey was to ascertain and document the surface radiological condition of the site subsequent to remedial action activities completed in May 1994. The survey was designed to determine whether any residual surface soil contamination in excess of $120 \mathrm{pCi} / \mathrm{g}{ }^{137} \mathrm{Cs}$ remained at the site.

Typical background surface gamma exposure rates (10 to $16 \mu \mathrm{R} / \mathrm{h})$ were found along the south fence except near the south entrance gate where a cluster of hot spots ranged from 20 to $175 \mu \mathrm{R} / \mathrm{h}$. Spotty contamination (with surface gamma levels ranging from 16 to $40 \mu \mathrm{R} / \mathrm{h}$ ) was found up to the edge of the former contaminated enclosures where excavation and soil replacement had taken place. Numerous hot spots ranging from 20 to $860 \mu \mathrm{R} / \mathrm{h}$ were scattered generally more toward the north side of the site. Several large areas (totaling $\left.-14,000 \mathrm{ft}^{2}\right)$ of elevated surface gamma exposure rates (20 to $\left.195 \mu \mathrm{R} / \mathrm{h}\right)$ were found north of the former contaminated enclosures. A marshy, drainage area paralleling the north fence for $-850 \mathrm{ft}$ also exhibited elevated surface gamma levels (16 to $40 \mu \mathrm{R} / \mathrm{h}$ ). Most surface gamma levels were $\leq 175 \mu \mathrm{R} / \mathrm{h}$; highest hot-spot measurements were 690 and $860 \mu \mathrm{R} / \mathrm{h}$.

Gamma spectrometry analysis of 1 vegetation sample collected where surface gamma exposure rates measured $690 \mu \mathrm{R} / \mathrm{h}$ showed elevated concentrations of ${ }^{137} \mathrm{Cs}(16 \pm 7 \mathrm{pCi} / \mathrm{g}$, dry wt). Eleven surface soil samples collected at locations ranging from 32 to $860 \mu \mathrm{R} / \mathrm{h}$ contained ${ }^{137} \mathrm{Cs}$ concentrations of $13 \pm 1$ to $9000 \pm 400 \mathrm{pCi} / \mathrm{g}$ (dry wt). Cesium-137 concentrations at depths of 0 to 6 in. exceeded $120 \mathrm{pCi} / \mathrm{g}$ in $80 \%$ of the samples. Concentrations at depths of 6 to 12 in. exceeded $120 \mathrm{pCi} / \mathrm{g}$ in $50 \%$ of the samples. Concentrations at depths of 12 to 18 in. were all $<120 \mathrm{pCi} / \mathrm{g}$.

Correlation of surface gamma exposure rates with ${ }^{137} \mathrm{Cs}$ levels in surface soil indicated that at locations where gamma radiation levels were $>40 \mu \mathrm{R} / \mathrm{h}$, concentrations of ${ }^{137} \mathrm{Cs}$ in surface soil were $>120 \mathrm{pCi} / \mathrm{g}$. Therefore, it should be conservatively assumed that all locations with surface gamma exposure rates $240 \mu \mathrm{R} / \mathrm{h}$ may have ${ }^{137} \mathrm{Cs}$ concentrations $>120 \mathrm{pCi} / \mathrm{g}$. Since surface gamma exposure rates at all six of the large areas and 75\% of the discrete spots or small areas equaled or exceeded $40 \mu \mathrm{R} / \mathrm{h}$, soil ${ }^{137} \mathrm{Cs}$ concentrations $>120 \mathrm{pCi} / \mathrm{g}$ can be assumed to be prevalent at this site. 


\section{INTRODUCTION}

A surface radiological investigation was conducted intermittently from July through September 1994 at the 0816 site, located within Waste Area Grouping (WAG) 13. The survey was performed by members of the Measurement Applications and Development Group, Health Sciences Research Division, Oak Ridge National Laboratory (ORNL) at the request of ORNL Site Environmental Restoration Program Facility Management. The purpose of the survey was to ascertain and document the surface radiological condition of the site subsequent to remedial action activities completed in May 1994. The survey was designed to determine whether any residual surface soil contamination in excess of $120 \mathrm{pCi} / \mathrm{g}{ }^{137} \mathrm{Cs}$ (specified by the Interim Record of Decision ${ }^{1}$ ) remained at the site. 


\section{SITE HISTORY}

The following background information taken from Radiation Exposures From a CesiumContaminated Field (ORNL/RAP-46) ${ }^{2}$ is useful in understanding the origin and extent of contamination at the site.

Because of civil defense interest in postattack survival, a weapons fallout field study was commissioned at the 0816 site during 1966 . The fallout study used ${ }^{137} \mathrm{Cs}$, an important longlived component of weapons fallout, as the source of radiation. This radionuclide has a 30 -year half-life and emits both beta $(0.52-$ and $1.18-\mathrm{MeV})$ and gamma $(0.66-\mathrm{MeV})$ radiation.

The 5-acre fenced 0816 site is part of the 0800 Environmental Research Area, a $~ 50$-acre fescue-dominated field located $330 \mathrm{ft}$ north of the Clinch River at Clinch River Mile 20.5. The study area is also located $\sim 1.3$ miles south of the intersection of Bethel Valley Road and State Highway 95 at ORNL grid coordinates (measured in feet) N 17,480, E 20,370.

Within the fenced area, eight 33- by $33-\mathrm{ft}$ treatment plots were enclosed by metal sheeting extending 18 in. below the surface and 24 in. above ground. In August 1968, enclosures $2,4,6$, and 7 were contaminated with ${ }^{137} \mathrm{Cs}$, and the remaining four enclosures were used as controls. (See Fig. 2.1.)

The contaminant consisted of ${ }^{137} \mathrm{Cs}$ fused at high temperatures to silica sand particles $(100 \mu \mathrm{Ci} / \mathrm{g})$. The particles ranged from 88 to $177 \mu \mathrm{m}$ in diameter and were spread at a load of $72 \mathrm{~g} / \mathrm{m}^{2}$ over the plots. Each enclosure received approximately $2.2 \mathrm{Ci}$ of ${ }^{137} \mathrm{Cs}$, which resulted in a total of $8.8 \mathrm{Ci}$ to the site. The particle-size distribution was selected to simulate particle diameters characteristic of weapons fallout.

A surface radiological investigation was conducted in the area between June 1987 and March 1988. Gamma exposure rates on the river and on Jones Island rarely exceeded background, but exposure rates on the shoreline at the closest point to the ${ }^{137} \mathrm{Cs}$-contaminated field approached three times background levels. Inside the fenced area, gamma rates at $1 \mathrm{~m}$ above the ground surface averaged 3 to $4 \mathrm{mR} / \mathrm{h}$ and measured $27 \mathrm{mR} / \mathrm{h}$ at the corner of one contaminated enclosure.

Between August and October 1993 the soil in the 4 contaminated enclosures was excavated to depths of 3 to $4.5 \mathrm{ft}$ and removed to underground silos at WAG $6 .^{3}$ As specified by the Interim Record of Decision for WAG $13,{ }^{1}$ excavation at each enclosure was terminated when laboratory results demonstrated residual contamination $\leq 120 \mathrm{pCi} / \mathrm{g}$ dry wt. ${ }^{3}$ Hot spots located within $10 \mathrm{ft}$ of the northern boundary of each contaminated enclosure and within 5 to $10 \mathrm{ft}$ of the east and west boundaries were excavated to a depth of 6 to $12 \mathrm{in}$. Hot spot excavation was completed in May $1994 .^{3}$ 


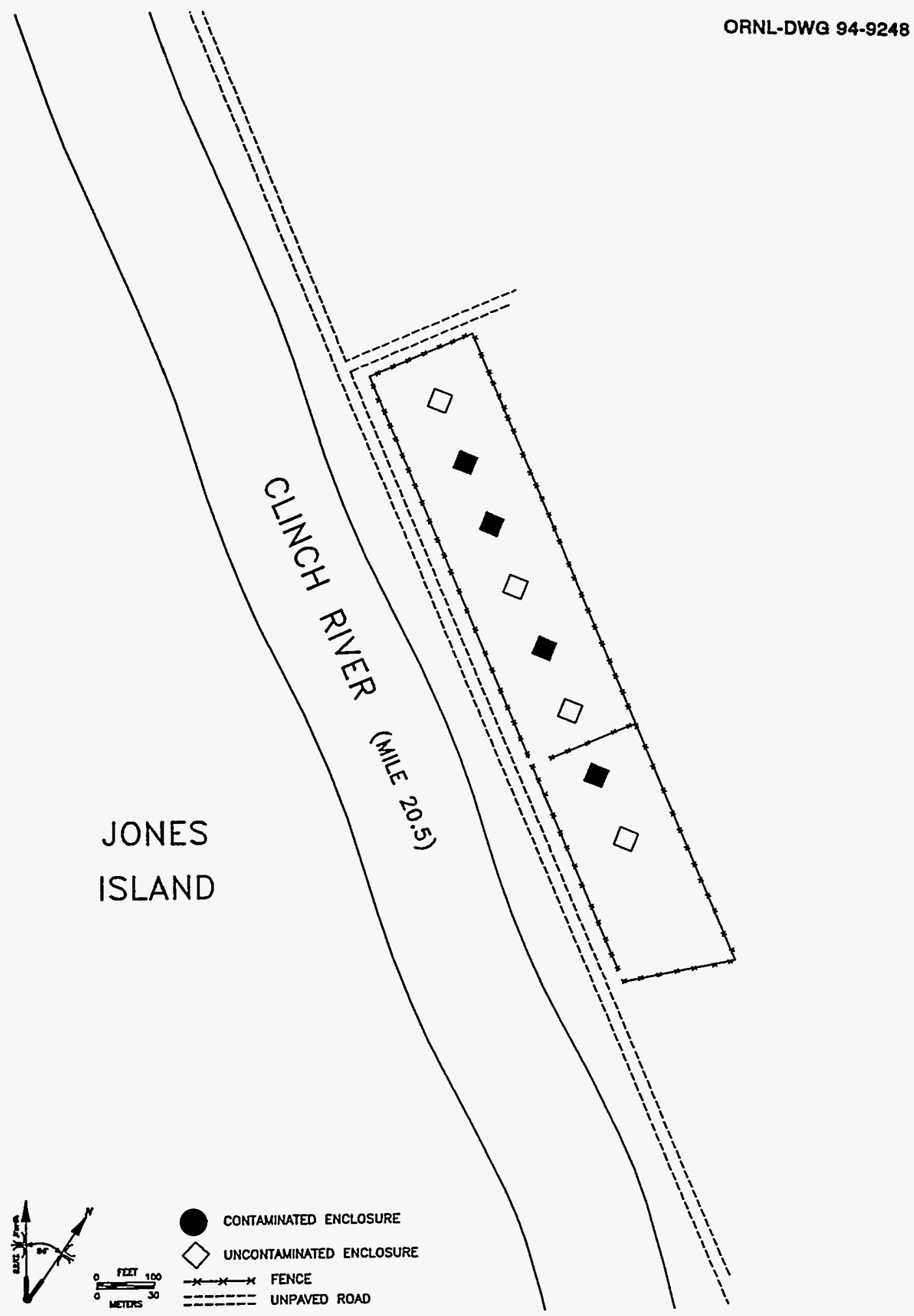

Fig. 2.1. Diagram of the 5-acre, fenced 0816 site used in ${ }^{137}$ Cs fallout studies in the 1960s. 


\section{SURVEY METHODS}

\subsection{GAMMA RADIATION}

Gamma radiation was measured with a sodium iodide ( $\mathrm{NaI})$ scintillation probe connected to a Victoreen Model 490 Thyac III ratemeter. Because NaI gamma scintillators are energydependent, measurements of gamma radiation levels made with these instruments must be normalized to pressurized ionization chamber (PIC) measurements to estimate gamma exposure rates. The function developed for these conversions is

$$
y=C F \times x+b
$$

where

$$
\begin{aligned}
y= & \text { the exposure rate }(\mu \mathrm{R} / \mathrm{h}), \\
\mathrm{CF}= & \text { the slope of the regression line calculated by plotting a selected number of PIC } \\
& \text { measurements }(\mu \mathrm{R} / \mathrm{h}) \text { vs scintillometer measurements }(\mathrm{kcpm}) \text { at the same } \\
& \text { locations, } \\
x= & \text { the scintillometer measurements in thousand counts per minute }(\mathrm{kcpm}), \\
\mathrm{b}= & \text { the y intercept. }
\end{aligned}
$$

For this site $C F=1.7$ and $b=6.2$.

\subsection{SECTIONING OF SURVEY AREA}

The 5-acre plot was divided into grid blocks to aid in identifying the location of contamination. The blocks were established by beginning at the southwest corner of the plot and measuring 100 -ft sections eastward along the fence. Each grid block covered the entire width of the plot, which varied from $175 \mathrm{ft}$ to $190 \mathrm{ft}$. Eleven rectangular blocks were established with dimensions of $100 \mathrm{ft}$ by $\sim 180 \mathrm{ft}$, and the twelfth block at the east end of the plot was a trapezoid. (See Fig. 3.1.)

\subsection{SCOPE OF THE SURVEY}

The survey included the following:

- Measurement of background gamma exposure rates outside the fence in areas deemed to be free of radiological contamination.

- A visual inspection for debris or any other indication of possibly contaminated material. 


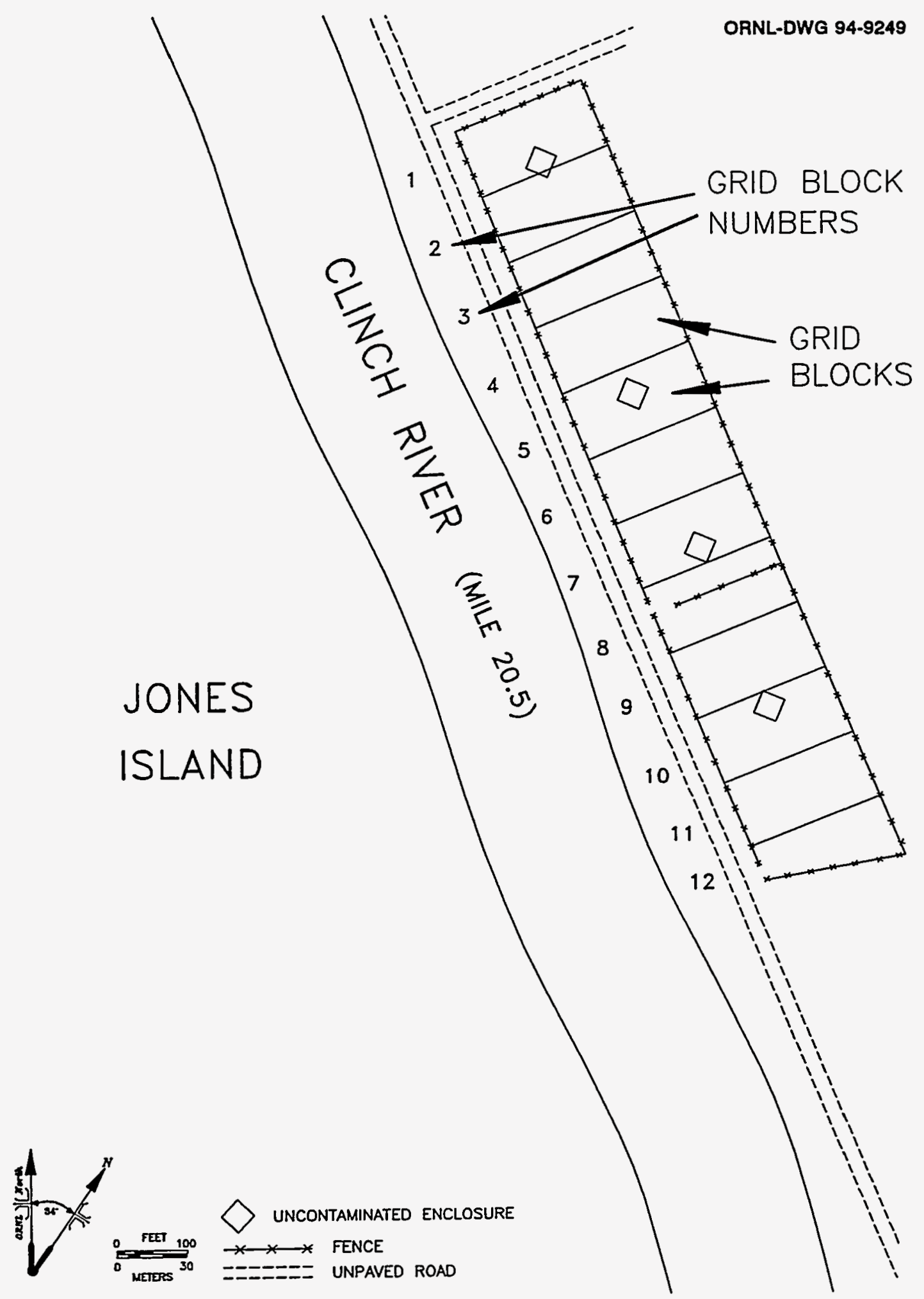

Fig. 3.1. Diagram showing Grid Blocks 1 through 12 established at the 0816 site. 
- A surface gamma radiation scan on all accessible portions of the 5-acre site. Approximately $95 \%$ of the site was accessible for surveying. (Inaccessible areas included locations where brush could not be cut or cleared due to the presence of debris, the control enclosures that remain in place, and the two buildings.) Areas with surface measurements $>40 \mu \mathrm{R} / \mathrm{h}$ were flagged and recorded.

- PIC measurements at 9 locations to enable calculation of a conversion factor.

- Collection of 23 soil samples at depths ranging from 6 to 18 in. at 11 locations throughout the site.

- Collection of 1 sample of vegetation growing in an area of contaminated soil.

- Gamma spectrometry analysis of the environmental samples conducted by the Analytical Services Organization at ORNL. 


\section{SURVEY RESULTS}

\subsection{GAMMA EXPOSURE RATES}

Background gamma exposure rates measured in uncontaminated areas on the Oak Ridge Reservation generally range from 8 to $13 \mu \mathrm{R} / \mathrm{h}$ at $1 \mathrm{~m}$ above ground surface and from 10 to $17 \mu \mathrm{R} / \mathrm{h}$ at the ground surface. ${ }^{4}$ Similar levels were measured outside the 0816 fence where gamma exposure rates ranged from 10 to $13 \mu \mathrm{R} / \mathrm{h}$ at $1 \mathrm{~m}$ above the ground surface and from 10 to $16 \mu \mathrm{R} / \mathrm{h}$ at the ground surface.

Results of the surface gamma scan inside the fence are shown in Figs. 4.1 and 4.2, with Grid Blocks 1 through 6 displayed in Fig. 4.1 and Blocks 7 through 12 displayed in Fig. 4.2. Surface gamma levels near the south fence of most blocks ranged from 10 to $16 \mu R / h$, similar to the typical background range. One grid block (No. 10) exhibited no elevated gamma radiation levels. In most blocks, gamma levels increased as the survey moved northward away from the south fence.

Grid Blocks 1 through 6 contained 3 large areas of surface contamination. The first area $\left(\sim 4500 \mathrm{ft}^{2}\right.$ in Grid Blocks 1 and 2) measured 20 to $44 \mu \mathrm{R} / \mathrm{h}$ in Block 1 , and 20 to $125 \mu \mathrm{R} / \mathrm{h}$ in Block 2. The second area ( $-2600 \mathrm{ft}^{2}$ in Grid Blocks 3 and 4$)$ measured 20 to $40 \mu \mathrm{R} / \mathrm{h}$. The third area $\left(-800 \mathrm{ft}^{2}\right.$ in Grid Block 6$)$ measured 32 to $90 \mu \mathrm{R} / \mathrm{h}$. Approximately 23 discrete contaminated spots or small areas were identified with 21 of these ranging from 32 to $175 \mu \mathrm{R} / \mathrm{h}$ and 2 measuring 690 and $860 \mu \mathrm{R} / \mathrm{h}$. One-meter gamma exposure rates measured at 5 soil sample locations varied from 23 to $92 \mu \mathrm{R} / \mathrm{h}$. Surface gamma levels at a marshy, drainage area running parallel to the north fence ranged from 16 to $40 \mu \mathrm{R} / \mathrm{h}$. ${ }^{*}$ The 2 experimental enclosures and a brushy area in Grid Block 5 were inaccessible.

Grid Blocks 7 through 12 contained 3 large areas of surface contamination. The first area $\left(-3100 \mathrm{ft}^{2}\right.$ in Grid Block 7) ranged from 32 to $195 \mu \mathrm{R} / \mathrm{h}$. The second area $\left(-2800 \mathrm{ft}^{2}\right.$ in Grid Blocks 8 and 9) ranged from 40 to $140 \mu \mathrm{R} / \mathrm{h}$. The third area ( $-600 \mathrm{ft}^{2}$ in Grid Block 12) ranged from 23 to $90 \mu \mathrm{R} / \mathrm{h}$. Approximately 27 discrete contaminated spots or small areas were identified with 24 of these ranging from 20 to 175 and 3 measuring 260,520 , and $690 \mu \mathrm{R} / \mathrm{h}$. One-meter gamma exposure rates measured $175 \mu \mathrm{R} / \mathrm{h}$ at one soil sample location. Surface gamma levels at the marshy, drainage area running parallel to the north fence in Grid Blocks 6 and 7 measured 20 to $40 \mu \mathrm{R} / \mathrm{h}$. The drainage area began at the $-2800 \mathrm{ft}^{2}$ area in Block 8 and 9 with surface gamma exposure rates ranging from 40 to $140 \mu R / h$ (described above). Two experimental enclosures and three brushy spots were inaccessible. The interior of the 2 buildings was not surveyed.

*As part of another survey, this marshy, drainage area was surveyed beyond the west fence and $-20 \mathrm{ft}$ west of the road. The marshy area drained beneath the road where it narrowed and became a small creek west of the road. The road was not contaminated. The highest surface gamma level found on the creek bank was $-23 \mu R / h$ with exposure levels quickly dropping to $-16 \mu R / h$ as the survey moved downstream. 
ORNL-DWG 94-9250

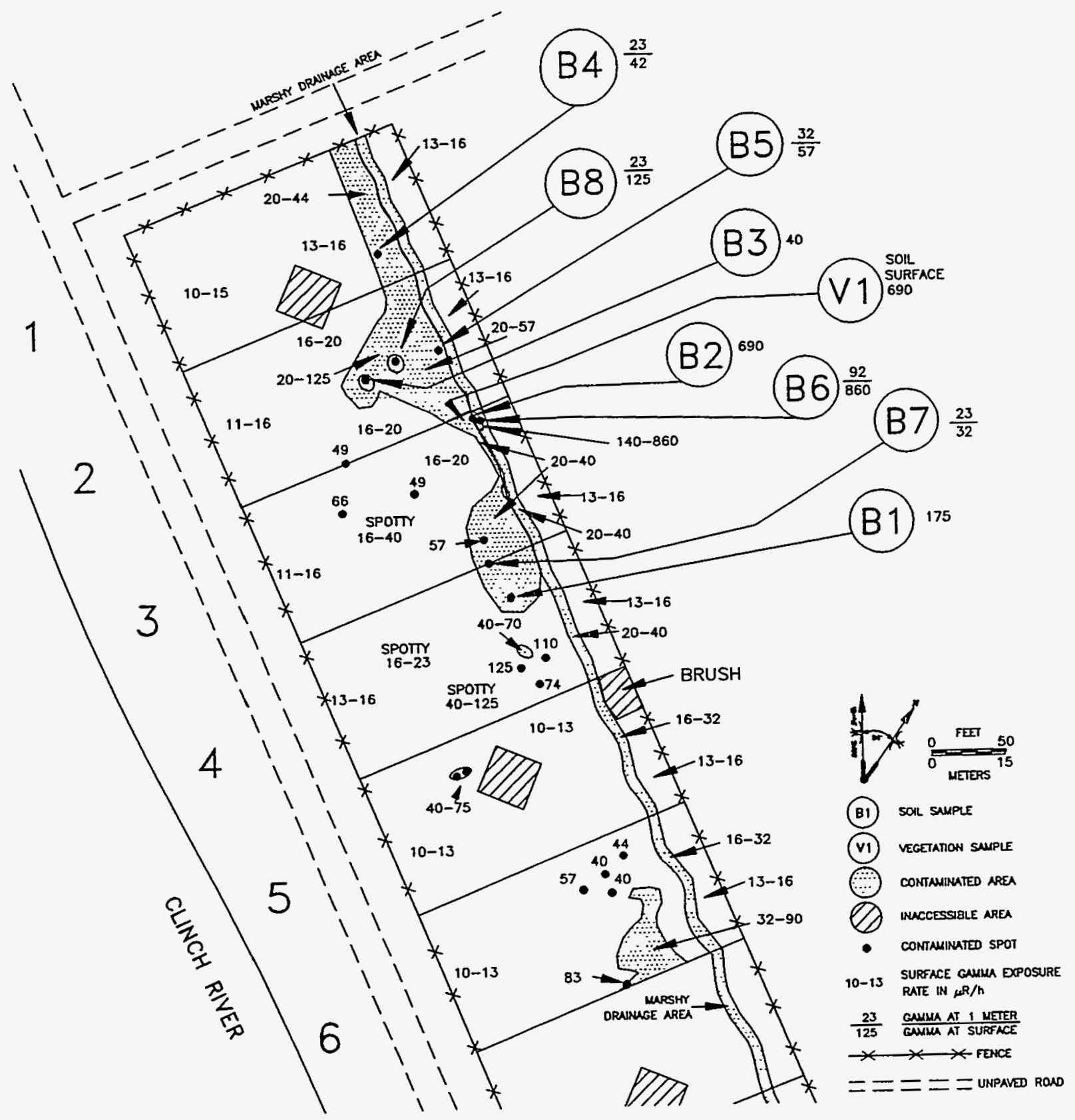

Fig. 4.1. Diagram showing surface and selected 1-m gamma exposure rates $(\mu R / h)$ in Grid Blocks 1 through 6 at the 0816 site. Locations of soil (B) and vegetation (V) samples are also indicated. 


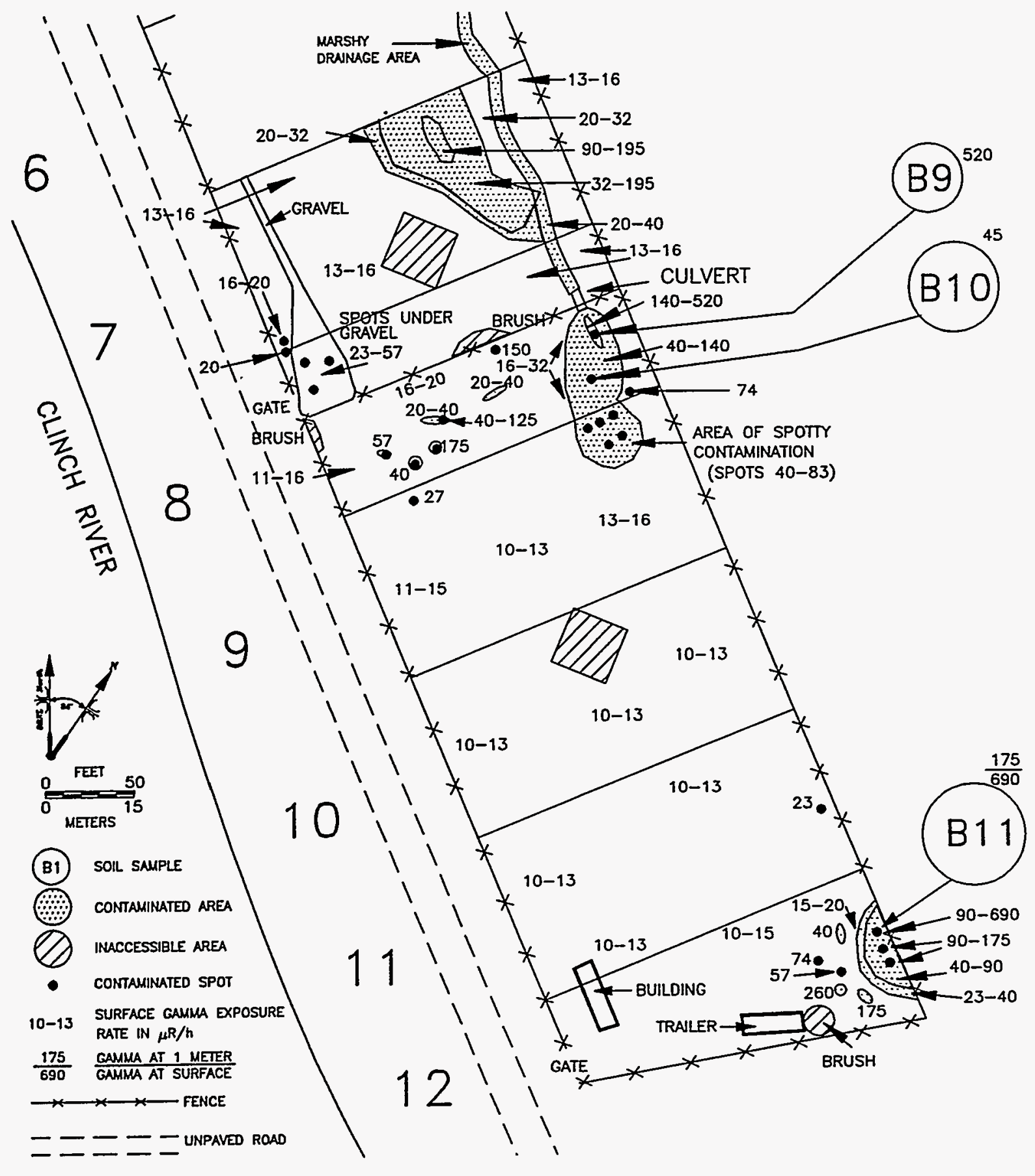

Fig. 4.2. Diagram showing surface gamma exposure rates $(\mu R / h)$ and soil sample locations (B) in Grid Blocks 7 through 12 at the 0816 site. 


\subsection{SOIL SAMPLE ANALYSES}

Results of soil sample analysis are given in Table 4.1, and sample locations are identified in Figs. 4.1 and 4.2. Surface gamma exposure rates at soil sample locations ranged from 32 to $860 \mu \mathrm{R} / \mathrm{h}$. Soil ${ }^{137} \mathrm{Cs}$ concentrations did not increase directly in relation to gamma exposure rates because only a small aliquot of the sample is randomly selected for analysis, and the radionuclides are seldom distributed uniformly throughout a sample.

Background ${ }^{137} \mathrm{Cs}$ concentrations measured at 4 sites outside the Oak Ridge Reservation having only natural radioactivity ranged from 0.35 to $0.6 \mathrm{pCi} / \mathrm{g}{ }^{5}$ When compared to these background levels, all soil samples collected during this survey contained elevated concentrations of ${ }^{137} \mathrm{Cs}$. Surface soil samples collected at depths of 0 to $6 \mathrm{in}$. ranged from 13 \pm 1 to $9000 \pm 400$ (dry wt) with ${ }^{137} \mathrm{Cs}$ concentrations exceeding $120 \mathrm{pCi} / \mathrm{g}$ in 9 of the 11 samples (80\%). Samples collected at depths of 6 to 12 in. varied from $4.3 \pm 0.6$ to $2900 \pm$ $40 \mathrm{pCi} / \mathrm{g}$ with ${ }^{137} \mathrm{Cs}$ concentrations exceeding $120 \mathrm{pCi} / \mathrm{g}$ in 4 of the 8 samples (50\%). Samples collected at depths of 12 to 18 in. ranged from $3.5 \pm 0.3$ to $85 \pm 3 \mathrm{pCi} / \mathrm{g}$ with ${ }^{137} \mathrm{Cs}$ concentrations $<120 \mathrm{pCi} / \mathrm{g}$ in all 4 samples. Except for sample $\mathrm{B} 2,{ }^{137} \mathrm{Cs}$ concentrations decreased with increasing depth.

\subsection{VEGETATION SAMPLE ANALYSIS}

One vegetation sample was collected in the vicinity of soil sample location B2 (Fig. 4.1) where surface gamma exposure rates measured $690 \mu \mathrm{R} / \mathrm{h}$ and ${ }^{137} \mathrm{Cs}$ soil concentrations measured $1200 \pm 30 \mathrm{pCi} / \mathrm{g}$ at 0 to $6 \mathrm{in}$. and $2900 \pm 40 \mathrm{pCi} / \mathrm{g}$ at 6 to $12 \mathrm{in}$. Radionuclide analysis (Table 4.1) showed that the vegetation contained elevated concentrations of ${ }^{137} \mathrm{Cs}$ $(16 \pm 7 \mathrm{pCi} / \mathrm{g}$, dry wt). 
Table 4.1. Concentrations of ${ }^{137} \mathrm{Cs}$ in soil (B) and vegetation (V) samples collected at the 0816 site

\begin{tabular}{|c|c|c|c|c|}
\hline $\begin{array}{l}\text { Sample } \\
\text { ID }\end{array}$ & $\begin{array}{c}\text { Sample } \\
\text { depth } \\
\text { (in.) }\end{array}$ & $\begin{array}{c}\text { Gamma exposure rate } \\
(\mu \mathrm{R} / \mathrm{h})\end{array}$ & $\begin{array}{c}{ }^{137} \mathrm{Cs}^{a} \\
\text { (pCi/g dry wt) }\end{array}$ & Comments \\
\hline B1 & $0-6$ & $\frac{175 \text { at surface }}{23 \text { at depth of } 6 \text { in. }}$ & $1200 \pm 30$ & Block 4; small spot \\
\hline B2A & $0-6$ & $\frac{690 \text { at surface }}{860 \text { at depth of } 6 \text { in. }}$ & $1200 \pm 30$ & $\begin{array}{l}\text { Block 3; area }-5 \times \\
8 \mathrm{ft}\end{array}$ \\
\hline B2B & $6-12$ & 350 at depth of $12 \mathrm{in.}$ & $2900 \pm 40$ & Same as B2A \\
\hline B3 & $0-6$ & 40 at surface & $13 \pm 1$ & $\begin{array}{l}\text { Block 2; area } \sim 10 \times \\
10 \mathrm{ft}\end{array}$ \\
\hline B4A & $0-6$ & $\begin{array}{l}23 \text { at } 1 \mathrm{~m} \\
42 \text { at surface } \\
44 \text { at depth of } 6 \mathrm{in} .\end{array}$ & $150 \pm 4$ & Block 1 \\
\hline B4B & $6-12$ & 23 at depth of 12 in. & $25 \pm 1$ & Same as B4A \\
\hline B5A & $0-6$ & $\begin{array}{l}32 \text { at } 1 \mathrm{~m} \\
57 \text { at surface } \\
57 \text { at depth of } 6 \mathrm{in} .\end{array}$ & $140 \pm 4$ & Block 2 \\
\hline B5B & $6-12$ & 32 at depth of 12 in. & $6 \pm 1$ & Same as B5A \\
\hline B6A & $0-6$ & $\begin{array}{l}92 \text { at } 1 \mathrm{~m} \\
\frac{860 \text { at surface }}{690 \text { at depth of } 6 \mathrm{in} .}\end{array}$ & $9000 \pm 400$ & Block 3 \\
\hline B6B & $6-12$ & 278 at depth of 12 in. & $680 \pm 30$ & Same as B6A \\
\hline $\mathrm{B} 6 \mathrm{C}$ & $12-18$ & 117 at depth of 18 in. & $85 \pm 3$ & Same as B6A \\
\hline B7 & $0-6$ & $\begin{array}{l}23 \text { at } 1 \mathrm{~m} \\
\underline{32 \text { at surface }}\end{array}$ & $45 \pm 3$ & $\begin{array}{l}\text { Boundary Block } 3 \text { and } \\
4\end{array}$ \\
\hline
\end{tabular}


Table 4.1. Concentrations of ${ }^{137} \mathrm{Cs}$ in soil (B) and vegetation (V) samples collected at the 0816 site

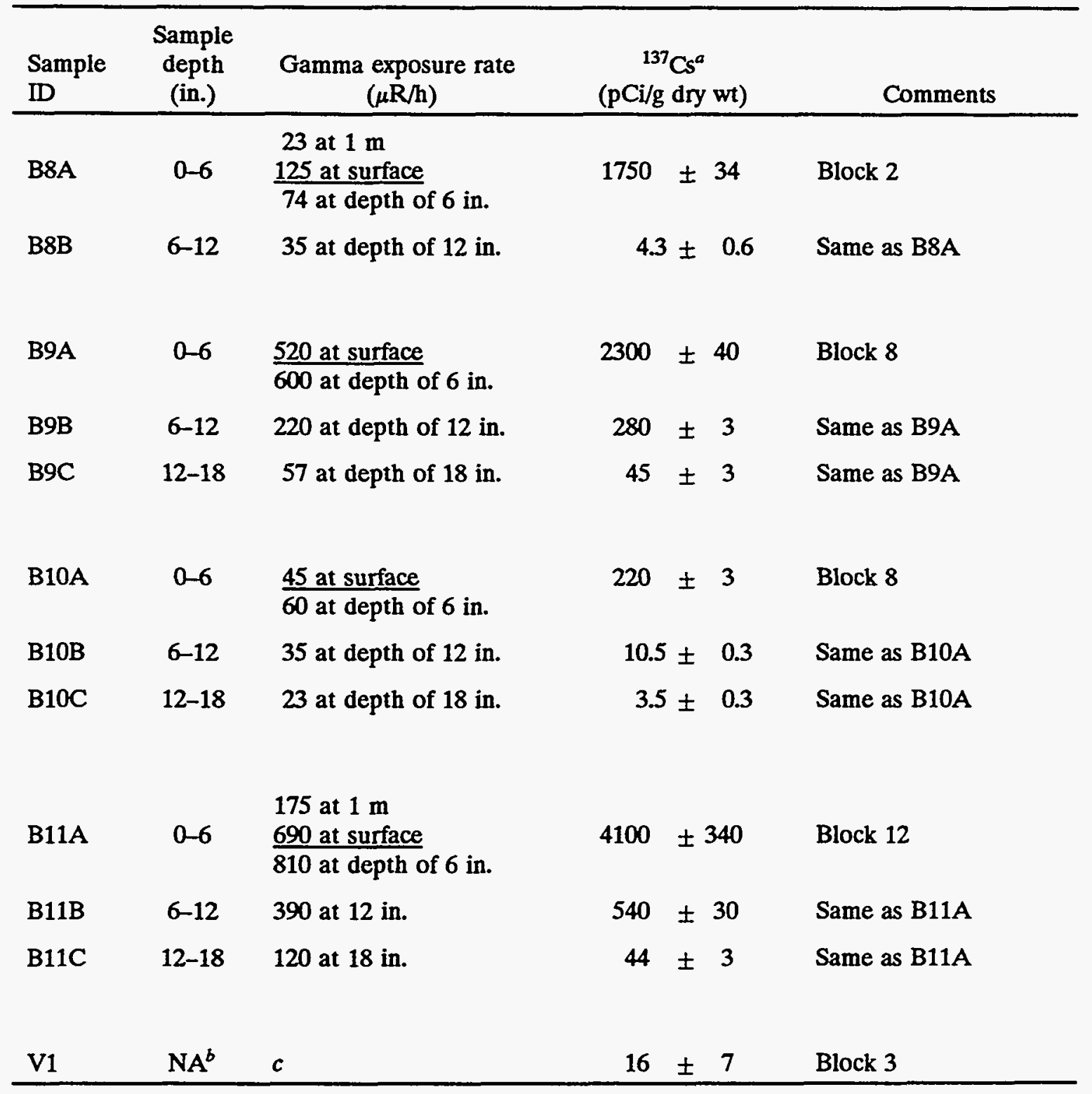

${ }^{a}$ Analytical Procedure No. EPA-901.1.

${ }^{b}$ Not applicable.

'Soil gamma exposure rate $690 \mu \mathrm{R} / \mathrm{h}$ at surface, $860 \mu \mathrm{R} / \mathrm{h}$ at depth of 6 in., and $350 \mu R / \mathrm{h}$ at depth of $12 \mathrm{in}$. 


\section{SIGNIFICANCE OF FINDINGS}

At the 0816 site, numerous hot spots ranging from 20 to $860 \mu \mathrm{R} / \mathrm{h}$ were scattered generally more toward the north side of the site. Several large areas (totaling $\sim 14,000 \mathrm{ft}^{2}$ ) of elevated surface gamma exposure rates (20 to $195 \mu \mathrm{R} / \mathrm{h}$ ) were found north of the former contaminated enclosures. Typical background surface gamma exposure rates (10 to $16 \mu \mathrm{R} / \mathrm{h}$ ) were found along the south fence except near the south entrance gate where a cluster of hot spots ranged from 20 to $175 \mu \mathrm{R} / \mathrm{h}$. Spotty contamination (with surface gamma levels ranging from 16 to $40 \mu \mathrm{R} / \mathrm{h}$ ) was found up to the edge of the former contaminated enclosures where excavation and soil replacement had taken place. A marshy, drainage area paralleling the north fence for $-850 \mathrm{ft}$ also exhibited elevated surface gamma levels (16 to $40 \mu \mathrm{R} / \mathrm{h}$ ). Most surface gamma levels were $s 175 \mu \mathrm{R} / \mathrm{h}$; highest hot-spot measurements were 690 and $860 \mu \mathrm{R} / \mathrm{h}$.

One vegetation sample collected from a contaminated area contained elevated concentrations of ${ }^{137} \mathrm{Cs}$ indicating that ${ }^{137} \mathrm{Cs}$ may be present in other vegetation found in similar areas of the $\mathbf{0 8 1 6}$ site. Soil samples collected at a range of surface gamma exposure rates contained ${ }^{137} \mathrm{Cs}$ at concentrations of $13 \pm 1$ to $9000 \pm 400 \mathrm{pCi} / \mathrm{g}$ (dry wt). Correlation of surface gamma exposure rates with ${ }^{137} \mathrm{Cs}$ levels in surface soil indicated that at locations where gamma radiation levels were $>40 \mu \mathrm{R} / \mathrm{h}$, concentrations of ${ }^{137} \mathrm{Cs}$ in surface soil were $>120 \mathrm{pCi} / \mathrm{g}$. Therefore, it should be conservatively assumed that all locations with surface gamma exposure rates $240 \mu \mathrm{R} / \mathrm{h}$ may have ${ }^{137} \mathrm{Cs}$ concentrations $>120 \mathrm{pCi} / \mathrm{g}$. Since surface gamma exposure rates at all six of the large areas and $75 \%$ of the discrete spots or small areas equaled or exceeded $40 \mu \mathrm{R} / \mathrm{h}$, soil ${ }^{137} \mathrm{Cs}$ concentrations $>120 \mathrm{pCi} / \mathrm{g}$ can be assumed to be prevalent at this site.

These data can be used in any subsequent verification of cleanup actions at the 0816 site; however, subsurface sampling and analysis are necessary to fully evaluate the radiological status of the site. 


\section{REFERENCES}

1. Interim Record of Decision for Oak Ridge National Laboratory Waste Area Grouping 13 Cesium Plots, Oak Ridge, Tennessee, DOE/OR-1059\&D4, Radian Corporation, Oak Ridge, Tennessee, September 1992.

2. M. G. Yalcintas, M. S. Uziel, J. A. Roberts, and I. Uslu, Radiation Exposures from a Cesium-Contaminated Field, ORNL/RAP-46, Martin Marietta Energy Systems, Inc., Oak Ridge Natl. Lab., September 1988.

3. P. M. Dawson and D. L. Garrett, Interim Remedial Action Postconstruction Report for Waste Area Grouping 13 at Oak Ridge National Laboratory, Oak Ridge, Tennessee, DOE/OR/01-1218\&D1, ORNL/ER-214\&D1, Martin Marietta Energy Systems, Inc., Oak Ridge Natl. Lab., June 1994.

4. M. S. Uziel, P. F. Tiner, and J. K. Williams, Surface Radiological Investigations at Environmental Research Area $11,{ }^{137} \mathrm{Cs}$ - and ${ }^{60} \mathrm{Co}$-Contaminated Plots, at Oak Ridge National Laboratory, Oak Ridge, Tennessee, ORNL/ER-138, Martin Marietta Energy Systems, Inc., Oak Ridge Natl. Lab., February 1993.

5. R. J. Maurer, Aerial Radiological Survey of the Oak Ridge Reservation and Surrounding Area, Oak Ridge Tennessee, Date of Survey: September 1989, EGG-10617-1123, EG\&G Energy Measurements, Inc., Remote Sensing Laboratory, Las Vegas, Nevada, April 1992. 
ORNL/ER-291

\section{DISTRIBUTION}

1-2. C. A. Bednarz

3. R. D. Foley

4-5 R. J. Howard

6. J. H. Hooyman

7-8. K A. McPherson

9. M. E. Murray

10-11. P. T. Owen

12-14. P. F. Tiner

15-17. M. S. Uziel

18-22. J. K. Williams

23. P. S. Wood

24-28. MAD Records Center

29. Central Research Library

30. ORNL Technical Library, Y-12

31. Laboratory Records Dept.

32-34. Central ER Doc. Managemnt. Ctr.

35-37. ORNL ER Doc. Management Ctr.

38. ORNL Patent Section

39. Office of Assistant Manager for Energy Research and Development, DOE Oak Ridge Operations Office, P.O. Box 2001, Oak Ridge, TN 37831-8600

40-41. Office of Scientific and Technical Information, P.O. Box 62, Oak Ridge, TN 37831 